\title{
Analisis Kemandirian Belajar Siswa Dalam Pembelajaran Daring Di Kelas III SDN Dayeuhluhur CBM
}

\author{
Mila Rahayu, Din Azwar Uswatun ${ }^{2}$, Andi Nurochmah ${ }^{3}$ \\ ${ }^{1}$ PGSD/FKIP/Universitas Muhammadiyah Sukabumi \\ Email: milarhy096@gmail.com \\ ${ }^{2}$ PGSD/FKIP/Universitas Muhammadiyah Sukabumi \\ Email: dinazwar@ummi.ac.id \\ ${ }^{3}$ PGSD/FKIP/Universitas Muhammadiyah Sukabumi \\ Email: andi.nurochmah@gmail.com
}

\begin{abstract}
This study aims to describe the independence of student learning and inhibiting factors in online learning in grade III SDN Dayeuhluhur CBM. This study use the descriptive qualitative research methods. The subject used in this study were the teacher and representatives of class III students. Data collection techniques in this study used interviews and documentation. Data analysis techniques use the stages of data reduction, data presentation and conclusions or verification. The result of this study is the independence of student learning in online learning in grade III SDN Dayeuhluhur CBM is quite well developed although there are still some students who lack confidence, active, disciplined and responsible for learning. The inhibiting factors that cause students to not be independent in the online learning is the emergence of boredom because they do not interact directly with the teacher, limited handphone used in online learning and still using parents handphone, fast quota runs out, unstable network, parents who are busy working and students lack understanding of the material. Due to several inhibiting factors in online learning, teachers have difficulty determining assessment and only rely on attendance in task collection.
\end{abstract}

Keyword: Independence of Learning; Online Learning; Primary School.

\begin{abstract}
Abstrak: Penelitian ini bertujuan untuk mendeskripsikan kemandirian belajar siswa dan faktor penghambat dalam pembelajaran daring di kelas III SDN Dayeuhluhur CBM. Penelitian ini menggunakan jenis penelitian metode kualitatif deskriptif. Subjek yang digunakan dalam penelitian ini yaitu guru dan perwakilan dari siswa kelas III. Teknik pengumpulan data dalam penelitian ini menggunakan wawancara dan dokumentasi. Teknik analisis data menggunakan tahapan reduksi data, penyajian data dan kesimpulan atau verifikasi. Hasil penelitian ini adalah kemandirian belajar siswa dalam pembelajaran daring di kelas III SDN Dayeuhluhur CBM cukup berkembang dengan baik meskipun masih ada beberapa siswa yang kurang percaya diri, aktif, disiplin dan tanggung jawab dalam belajar. Faktor penghambat yang menyebabkan siswa belum mandiri dalam proses pembelajaran daring adalah timbulnya rasa bosan karena tidak berinteraksi langsung dengan guru, terbatasnya handphone yang digunakan dalam pembelajaran daring dan masih memakai handphone orang tua, kuota yang cepat habis, jaringan yang tidak stabil, orang tua yang sibuk serta kurang dapat memahami materi. Akibat beberapa faktor penghambat dalam pembelajaran daring, guru kesulitan dalam menentukan penilaian dan hanya mengandalkan kehadiran dalam pengumpulan tugas.
\end{abstract}

Kata Kunci: Kemandirian Belajar; Pembelajaran Daring; Sekolah Dasar. 


\section{PENDAHULUAN}

Perkembangan zaman yang begitu pesat dewasa ini menuntut sumber daya manusia yang berkualitas dan mampu berkompetensi. Salah satu cara untuk meningkatkan kualitas sumber daya manusia yaitu melalui pendidikan. Pendidikan merupakan usaha yang sudah terencana untuk mewujudkan proses pembelajaran yang menyenangkan bagi siswa agar dapat mengembangkan segala potensi yang dimilikinya.

Pendidikan di Indonesia saat ini dapat dikatakan belum berhasil atau belum berjalan dan berkembang dengan baik seperti pendidikan di negara-negara lainnya. Hal tersebut dikarenakan banyak permasalahan yang timbul maupun yang sedang dihadapi bangsa Indonesia saat ini. Kualitas pendidikan di Indonesia terbilang rendah, sesuai dengan apa yang dikemukakan oleh Fatihah (2016: 198) bahwa kualitas pendidikan di Indonesia saat ini begitu memprihatinkan. Dari data balitbang menunjukkan bahwa pendidikan di Indonesia masih terbilang rendah yaitu hanya delapan sekolah saja yang mendapat pengakuan dunia dalam kategori The Primary Years Program (PYP) dari jumlah keseluruhan sekolah yang mencakup sekitar 146.052 sekolah dasar di Indonesia. Penyebab dari rendahnya kualitas pendidikan di Indonesia di picu karena pembentukkan karakter siswa yang masih rendah. Maka dari itu pendidikan dikatakan berkualitas apabila mengarah pada pembentukkan karakter siswa secara optimal. Pada dasarnya pendidikan karakter tidaklah terlepas dari kemandirian siswa ketika belajar maupun mengerjakan tugas-tugas yang diberikan guru. Karena nilai kemandirian dijenjang sekolah dasar yang paling dasar yaitu dapat berdiri sendiri tanpa bergantung pada orang lain.

Pengetahuan dalam proses pendidikan adalah hal yang harus didapatkan oleh semua orang. Akan tetapi di era pendidikan saat ini sedang mengalami masa-masa berduka, dikarenakan Indonesia dan negara-negara lain di dunia tengah tertimpa musibah besar yaitu terjadinya wabah penyakit covid-19 ditahun 2020 ini. Covid-19 kemudian dinyatakan sebagai pandemi dan mulai memberi dampak pada kegiatan masyarakat di dunia, khususnya dalam bidang pendidikan. Meskipun sekolah ditutup namun kegiatan pembelajaran tidak berhenti, berdasarkan surat edaran Menteri pendidikan dan kebudayaan bahwa seluruh kegiatan pembelajaran dilakukan dengan sistem pembelajaran daring di rumah. Hal tersebut didukung dengan pesatnya kemajuan teknologi informasi dan komunikasi (TIK) dalam berbagai kehidupan saat ini. Menurut Yanti et al. (2020: 62) pengaruh besar TIK di bidang Pendidikan adalah munculnya terobosan baru yang mulai memanfaatkan jaringan komputer dan internet dalam kegiatan pembelajaran yang sering disebut dengan e-learning atau pembelajaran elektronik. Dari istilah e-learning kemudian berkembang lagi menjadi pembelajaran daring (online learning). "Pembelajaran daring merupakan program penyelenggaraan dalam jaringan untuk menjangkau kelompok target yang masif dan luas dengan internet" (Bilfaqih \& Qomarudin, 2015: 1). Maka dari itu sekolah mengalihkan semua kegiatan pembelajaran dilakukan antara guru dengan siswa secara jarak jauh dengan memanfaatkan teknologi, informasi dan komunikasi (TIK).

Belajar merupakan suatu aktivitas atau suatu proses untuk memperoleh pengetahuan, meningkatkan keterampilan, memperbaiki tingkah laku, sikap dan mengokohkan kepribadian (Suyono \& Hariyanto, 2016: 9). Setiap siswa memiliki tipe dan gaya belajar, hal tersebut karena setiap siswa mempunyai kemampuan yang berbeda satu sama lainnya. Kemandirian dalam belajar harus diberikan pada siswa agar mampu untuk bertanggung jawab dalam mendisiplinkan dirinya dan mengembangkan kemampuan belajar sesuai dengan kemampuan sendiri.

Kemandirian merupakan salah satu faktor yang menentukan keberhasilan belajar siswa, sehingga sikap mandiri penting untuk dimiliki oleh seseorang agar keberhasilan yang diinginkannya dapat tercapai. Pendidikan kemandirian yang diberikan pada siswa dimaksudkan agar siswa dapat mengembangkan potensi dan kemampuannya dalam menyelesaikan semua tugas-tugasnya. Selain sikap mandiri dari siswa, untuk membentuk kemandiriannya perlu peranan dari orang tua dan guru sebagai pembimbing proses kemandirian siswa tersebut (Suhandi \& Kurniasari, 2019: 126). Maka kemandirian belajar sangatlah penting, karena kemandirian belajar bertujuan agar dapat mengarahkan diri siswa ke arah yang positif dan siswa dapat bertanggung 
jawab dalam mengatur serta mendisiplinkan dirinya.

Proses pembelajaran yang dilakukan selama masa pandemi covid-19 untuk melihat kemandirian belajar siswa adalah dengan memanfaatkan media handphone dan penggunaan internet agar guru dan siswa saling terhubung untuk melaksanakan kegiatan pembelajaran daring. Menurut Mudjiman (dalam Isnawati \& Samian, 2015: 131) bahwa Kemandirian belajar mempunyai empat indikator yaitu, 1) percaya diri, 2) aktif dalam belajar, 3) disiplin, 4) tanggung jawab dalam belajar. Empat indikator tersebut menjadi acuan terhadap penelitian ini untuk mengetahui sejauh mana kemandirian belajar yang dimiliki oleh siswa.

Berdasarkan pemaparan yang sudah dijelaskan, maka peneliti terdorong untuk memberikan gambaran terkait kemandirian belajar siswa di kelas III SDN Dayeuhluhur CBM dan memberikan gambaran terkait faktor penghambat guru dalam melaksanakan proses pembelajaran daring, khususnya selama proses pembelajarannya dilaksanakan ditengah kondisi pandemi covid-19. Oleh karena itu, peneliti akan meneliti bagaimana dan apa saja berdasarkan analisis kemandirian belajar siswa dalam pembelajaran daring di kelas III SDN Dayeuhluhur CBM.

\section{METODE}

Jenis penelitian ini menggunakan metode penelitian deskriptif kualitatif, karena akan menganalisis sebuah permasalahan dan data-data yang dikumpulkan berupa kata-kata, gambar dan bukan berupa angka. Penulis melakukan kegiatan penelitian deskriptif ini secara alamiah, yaitu dalam penelitian ini penulis harus menyesuaikan diri secara alami dengan kondisi sekarang terutama di saat masa pandemi covid-19 yang proses pembelajarannya dilakukan secara daring.

Desain penelitian yang digunakan yaitu analisis deskriptif, di mana hasil dari analisis disajikan dalam bentuk deskriptif melalui hasil menelaah, mengkaji dan menyimpulkan. Sampel pada penelitian ini adalah siswa kelas III SDN Dayeuhluhur CBM Kota Sukabumi. Sampel diambil dengan menggunakan teknik purposive sampling yang berarti pengambilan sampel dilakukan dengan pertimbangan tertentu.
Teknik pengumpulan data dengan wawancara dan dokumentasi. Wawancara dilakukan kepada guru dan siswa kelas III B. Wawancara dengan guru dilakukan secara langsung sedangkan untuk siswa dilakukan melalui chat di aplikasi WhatsApp karena terbatas dengan keadaan akibat adanya pandemi covid-19. Menurut Sugiyono (2015: 320) "tujuan dari wawancara ini adalah untuk menemukan permasalahan secara lebih terbuka, di mana pihak yang diajak wawancara diminta pendapat dan ide-idenya".

Adapun untuk pertanyaan-pertanyaan yang diajukan pada saat pelaksanaan wawancara akan difokuskan ke dalam beberapa hal berikut:

1. Kemandirian belajar dan indikator kemandirian belajar yang terdapat di kelas III.

2. Faktor-faktor penghambat dalam membentuk kemandirian belajar siswa.

Data diperoleh dari hasil wawancara kepada guru dan perwakilan siswa kelas III B SDN Dayeuhluhur CBM. Selanjutnya data yang terkumpul dianalisis untuk dideskripsikan oleh penulis. Dokumentasi yang dilakukan berupa hasil foto bersama guru dan hasil tangkapan layar (screenshot) percakapan chat dengan siswa. Menurut Miles and Huberman (dalam Sugiyono, 2015: 337) "aktivitas dalam analisis data kualitatif dilakukan secara interaktif dan berlangsung secara terus menerus sampai tuntas, sehingga datanya jenuh". Teknik analisis data yang digunakan pada penelitian ini sesuai pendapat Siyoto \& Sodik (2015: 122) jika proses tahapan analisis data dilakukan melalui tahapan yaitu, reduksi data (data reduction), penyajian data (data display) dan kesimpulan atau verifikasi (conclusion or verification).

\section{HASIL DAN PEMBAHASAN}

\section{Hasil}

\section{Hasil Penelitian}

Berdasarkan hasil penelitian yang didapatkan dari wawancara semiterstruktur yang dilakukan secara langsung dengan guru dan melalui daring di WhatsApp dengan siswa. Tujuan dari wawancara ini dilakukan untuk mendapatkan informasi berupa kemandirian belajar siswa dan faktor penghambat dalam pembelajaran daring di kelas III SDN Dayeuhluhur CBM. Berikut pemaparan 
hasil penelitian yang sudah didapatkan oleh penulis:

a. Wawancara Guru

Penulis melakukan wawancara dengan narasumber guru kelas III B di SDN Dayeuhluhur CBM pada tanggal 2 Juli 2020 bertempat di salah satu ruangan kelas. Adapun hasil wawancara yang didapatkan sebagai berikut:

a) Kemandirian belajar dan indikator kemandirian belajar yang terdapat di kelas III.

Guru kelas memaparkan bahwa kemandirian belajar itu bertanggung jawab atas diri sendiri sesuai tingkatan masing-masing. Seperti tanggung jawab terhadap tugas-tugas yang harus dikerjakan. Kemandirian belajar siswa ketika pembelajaran daring terbilang cukup baik karena siswa sudah memahami apa yang harus dilakukan saat belajar di rumah tanpa pantauan dari guru. Siswa terlihat memiliki antusiasme yang tinggi terbukti dari banyak siswa yang mengirimkan bukti foto ataupun video dalam mengikuti kegiatan pembelajaran.

\section{1) Percaya Diri}

Hasil wawancara yang didapatkan terkait indikator pertama dari kemandirian belajar yang terdapat dalam penelitian ini yaitu ingin mendeskripsikan terkait kepercayaan diri siswa dalam proses pembelajaran daring. Guru kelas mengatakan bahwa kepercayaan diri siswa sudah cukup baik terutama ketika mengumpulkan tugastugasnya walaupun isi dari jawabannya itu ada yang salah. Siswa merasa percaya diri dalam mengumpulkan tugas mungkin karena merasa tidak terpantau oleh guru kemudian ketika sudah selesai mengerjakan tugas langsung saja dikirimkan hasilnya kepada guru entah itu hasilnya benar ataupun salah. Akan tetapi terkadang ada juga siswa yang harus terus menerus di beritahu guru bahwa sudah waktunya mengumpulkan tugas. Ketika ditanyakan alasannya adalah takut kalau jawabannya banyak yang salah.

\section{2) Keaktifan Belajar}

Indikator kedua yaitu ingin mendeskripsikan keaktifan belajar siswa dalam pelaksanaan pembelajaran daring. Guru kelas mengatakan bahwa keaktifan belajar siswa dalam pembelajaran daring berbeda dengan pembelajaran secara tatap muka. Kesulitan untuk membuat siswa aktif dalam pembelajaran daring yaitu mengkondisikan siswa agar semuanya dapat mengikuti kegiatan pembelajaran. Kendala tersebut dikarenakan adanya keterbatasan handphone yang digunakan siswa seperti sulitnya tersambung dengan aplikasi WhatsApp karena handphone tersebut belum sesuai dengan teknologi saat ini. Sekitar $70 \%$ siswa yang rajin dalam mengumpulkan tugas-tugasnya. Kemudian proses penilaian dari keaktifan siswa terutama saat proses pembelajaran daring ini guru menilai pada saat siswa mengumpulkan tugas dengan rajin dan tepat waktu.

\section{3) Disiplin Belajar}

Indikator ketiga yaitu penulis ingin mendeskripsikan kedisiplinan belajar siswa dalam pembelajaran daring. Guru kelas mengatakan bahwa kedisiplinan belajar siswa dalam pembelajaran daring yaitu siswa harus terbiasa untuk mengetahui jam belajar ketika di rumah. Bahkan sebelum proses pembelajaran dimulai siswa harus sudah menyiapkan dirinya sebaik mungkin, mulai dari menyiapkan peralatan tulis dan menyiapkan handphone yang digunakan sebagai media pembelajaran jarak jauh. Kemudian siswa juga diminta untuk mencari sendiri materi yang berhubungan dengan tugas yang diberikan dengan bimbingan dan pengawasan dari pihak orang tua.

\section{4) Tanggung Jawab}

Selanjutnya untuk indikator terakhir penulis ingin mendeskripsikan terkait tanggung jawab siswa dalam pembelajaran daring. Guru kelas mengatakan bahwa tanggung jawab siswa dalam belajar terbilang penting dalam proses pembelajaran. Hal ini disebabkan karena dengan tanggung jawab siswa harus berusaha sendiri dalam mengerjakan tugas-tugasnya tanpa harus dibantu oleh orang lain. Kemandirian belajar juga menuntut siswa untuk tetap yakin pada dirinya sendiri agar bisa menyelesaikan tugas-tugasnya tanpa harus dibantu ataupun dikerjakan oleh orang lain. Hanya saja dalam pembelajaran daring ini media handphone yang digunakan cukup terbatas karena terkendala dengan usia siswa yang belum memiliki handphone sendiri. Hampir semua siswa menggunakan handphone orang tua dan terkadang terkendala juga dengan orang tua siswa yang sibuk bekerja serta pada akhirnya siswa tertinggal informasi terkait tugas yang diberikan guru. 
b) Faktor-faktor penghambat dalam membentuk kemandirian belajar siswa.

Faktor-faktor penghambat dalam membentuk kemandirian belajar siswa dalam pembelajaran daring sangat bervariasi. Maka dari itu penulis ingin mendeskripsikan lebih lanjut terkait faktor penghambat dalam membentuk kemandirian belajar siswa. Banyak faktor penghambat guru ketika membentuk kemandirian belajar siswa pada saat pembelajaran daring. Guru tidak dapat memantau langsung kegiatan pembelajaran yang dilakukan siswa utamanya ketika mengerjakan tugas apakah memang dikerjakan sendiri ataukah oleh orang lain. Media handphone yang digunakan masih memakai handphone orang tua sehingga guru tidak bisa leluasa dalam menyampaikan materi terlebih dahulu. Karena usia kelas rendah itu terbilang usia yang sangat membutuhkan bimbingan dari guru ketika di sekolah dan orang tua ketika di rumah terutama saat pembelajaran daring. Hal tersebut dapat menyebabkan siswa mudah bosan dalam belajar terutama di jarak jauh seperti ini.

\section{Pembahasan}

a. Kemandirian belajar dan indikator kemandirian belajar yang terdapat di kelas III.

Kemandirian belajar menuntun siswa untuk mencapai keberhasilan yang diinginkannya. Maka dari itu kemandirian merupakan salah satu faktor yang menentukan keberhasilan belajar siswa, sehingga sikap mandiri penting untuk dimiliki oleh seseorang agar keberhasilan yang diinginkannya dapat tercapai. Menurut teori Suhandi \& Kurniasari (2019: 126) mengatakan bahwa pendidikan kemandirian yang diberikan pada siswa dimaksudkan agar siswa dapat mengembangkan potensi dan kemampuannya dalam menyelesaikan semua tugas-tugasnya.

\section{1) Percaya Diri}

Berdasarkan hasil penelitian rasa percaya diri tidak akan muncul dengan sendirinya, hal tersebut harus didorong dengan meningkatkan komunikasi pihak orang tua maupun guru dengan siswa. Maka saat pembelajaran daring ini peran guru harus lebih meningkatkan komunikasi dengan orang tua siswa agar dapat membuat siswa termotivasi untuk belajar secara mandiri dan mengumpulkan tugas dengan tepat waktu. Menurut teori yang dijelaskan oleh Hakim (dalam Syam \& Amri, 2017: 91) rasa percaya diri itu tidak akan muncul dengan begitu saja bahkan ada proses tertentu didalam pribadi seseorang seperti adanya proses interaksi dilingkungannya secara berkesinambungan sehingga terjadilah pembentukan rasa percaya diri.

\section{2) Keaktifan Belajar}

Berdasarkan hasil penelitian siswa dikatakan aktif apabila selalu mengikuti proses pembelajaran daring dengan baik sesuai alur yang dilakukan oleh guru. Kemudian keaktifan siswa pada saat mengikuti proses pembelajaran ini tergantung dari faktor lingkungan yang mempengaruhinya. Menurut teori Yustika \& Prihatnani (2019: 482) menyatakan jika faktor lingkungan tersebut selalu memberikan motivasi dan membimbing siswa, maka keaktifan belajarnya juga akan berkembang. Pada dasarnya keaktifan merupakan unsur yang sangat berpengaruh dan berperan penting terhadap keberhasilan dari suatu proses pembelajaran. Kemudian siswa dapat dikatakan berhasil apabila aktif dalam belajarnya, meskipun pelaksanaannya harus dengan pembelajaran secara daring. Akan tetapi dalam pembelajaran daring guru mengalami kesulitan dalam mengkondisikan siswa agar aktif dikarenakan handphone yang dipakai masih memakai handphone orang tua siswa.

\section{3) Disiplin Belajar}

Berdasarkan hasil penelitian bahwa disiplin itu harus mengikuti segala peraturan yang ditetapkan oleh guru dalam melaksanakan pembelajaran daring. Mulai dari mengetahui jam belajar, mengikuti pembelajaran dengan disiplin, mencari sendiri materi yang berkaitan dengan bahan ajar, dan menyelesaikan tugas dengan tepat waktu.

Menurut teori Ariananda et al. (2014: 234) disiplin merupakan sikap mental yang mengandung kerelaan dalam mematuhi semua ketentuan peraturan dan norma yang berlaku dalam mengerjakan tugas dan bertanggung jawab tanpa adanya paksaan dari siapapun. Rasa disiplin itu dapat terjadi akibat dorongan kesadaran dari dalam diri seseorang tapi ada pula yang terjadi karena adanya pemaksaan dan tekanan dari luar diri seseorang tersebut.

\section{4) Tanggung Jawab}

Berdasarkan hasil penelitian seorang siswa harus memiliki sikap tanggung jawab terutama tanggung jawab untuk belajar karena hal tersebut penting untuk ditanamkan. Tanggung jawab siswa diukur pada tugas yang dikerjakannya dilakukan 
dengan tepat waktu secara sendiri, cukup banyak siswa yang berusaha mengumpulkan tugasnya dengan tepat waktu. Menurut teori Prayitno (Suryadi, Erlamsyah, \& Yusri, 2016: 14) "keterampilan menyelesaikan tugas merupakan bagian dari proses pembelajaran, tujuan utamanya adalah membelajarkan siswa. Melalui tugas-tugas itu siswa dituntut untuk mengerjakannya dengan mencari bahan, mempelajari dan mengkaji lebih lanjut. Mengerjakan tugas-tugas tertentu dapat memperoleh pemahaman dan keterampilan baru sesuai dengan materi tugas".

Pada dasarnya pemberian tugas secara terus menerus yang diberikan guru untuk siswa dikarenakan proses pembelajarannya dilakukan secara daring, dengan tugas tersebut dapat membuat siswa menjadi lebih mandiri dan bertanggung jawab untuk menyelesaikan tugastugasnya. Menurut teori Yasmin, Santoso, \& Utaya (2016: 693) menyatakan jika pemberian tugas itu mempunyai kelebihan yaitu bisa mengembangkan daya pikir siswa, kreativitas, kemandirian serta tanggung jawab terhadap kewajiban belajarnya.

b. Faktor-faktor penghambat dalam membentuk kemandirian belajar siswa.

Proses pembelajaran dilakukan secara daring, guru dituntut agar mempunyai metode pembelajaran yang beragam karena meskipun pembelajaran dilakukan secara jauh dengan adanya metode yang bervariasi dapat membuat siswa lebih aktif dalam proses pembelajarannya. Menurut teori Trianto (dalam Nasution, 2017: 9) menyatakan bahwa "Metode pembelajaran adalah suatu perencanaan atau pola yang digunakan sebagai pedoman dalam merencanakan pembelajaran di kelas atau pembelajaran tutorial".

Pembelajaran daring yang dilakukan dalam dunia pendidikan saat ini, guru dan siswa banyak mendapat kendala yang cukup berpengaruh dalam proses belajarnya. Adapun menurut Purwanto et al. (2020: 7) terkait pembelajaran daring yaitu karena pembelajaran daring merupakan proses pembelajaran yang terbilang baru untuk dilakukan guru dan siswa di sekolah yang penulis jadikan tempat penelitian. Guru harus membiasakan dirinya untuk terus beradaptasi dengan pembelajaran daring ini dan harus menghadapi perubahan baru yang secara tidak langsung mempengaruhi kualitas hasil belajar siswa.
Walaupun banyak terdapat faktor-faktor penghambat dalam membentuk kemandirian belajar siswa, guru masih tetap menjalankan proses pembelajaran daring dengan baik melalui aplikasi WhatsApp. Menurut pernyataan Zakirman \& Rahayu (2018: 29) "WhatsApp merupakan teknologi instant massaging seperti SMS dengan bantuan internet berfitur pendukung yang lebih menarik, sehingga WhatsApp dipandang dapat menjadi media komunikasi dan akademik yang praktis dan efektif". Guru menggunakan aplikasi WhatsApp ini agar memudahkan dalam memberikan materi berbentuk gambar ataupun video pembelajaran yang relevan dengan materi pelajaran dengan tujuan menarik minat belajar siswa.

Faktor-faktor yang menjadi penghambat dalam membentuk kemandirian belajar siswa terdapat dalam dua faktor, yaitu faktor internal yang terdapat dalam diri siswa dan faktor eksternal yang terdapat dilingkungan sekitar siswa itu sendiri. Hal tersebut sesuai dengan teori menurut Basri (dalam Rijal \& Bachtiar, 2015: 18) menyatakan dua faktor yang mempengaruhi kemandirian belajar yaitu:

1) faktor internal datang dan bersumber dari dalam dirinya sendiri (internal), seperti keadaan keturunan dan keadaan tubuhnya sejak dilahirkan dengan segala perlengkapan yang melekat padanya. Segala sesuatu yang dibawa dari lahir merupakan bekal dasar bagi pertumbuhan dan perkembangan individu selanjutnya. Bermacam-macam sifat dasar dari ayah dan ibu kemungkinan akan didapatkan dalam diri seseorang, seperti halnya bakat, potensi intelektual dan potensi pertumbuhan tubuhnya.

2) Faktor eksternal yaitu semua keadaan atau pengaruh yang berasal dari luar diri seseorang, sering dinamakan dengan faktor lingkungan. Lingkungan kehidupan luar yang dihadapi oleh individu sangat mempengaruhi sekali terhadap perkembangan kepribadian seseorang, baik dalam segi negative maupun positif. Lingkungan keluarga maupun masyarakat yang baik terutama dalam suatu nilai dan kebiasaan-kebiasaan hidup yang baik akan membentuk kepribadian, termasuk pula dalam hal kemandiriannya tersebut. 
Maka dengan demikian seseorang yang memiliki kemandirian belajar yaitu apabila memiliki rasa percaya diri dalam belajar, aktif belajar walaupun pembelajaran dilaksanakan secara daring, disiplin dalam mengerjakan tugas dengan tepat waktu dan bertanggung jawab menyelesaikan tugasnya dengan baik.

\section{SIMPULAN DAN SARAN}

Kemandirian belajar siswa dalam pembelajaran daring di kelas III SDN Dayeuhluhur CBM sudah terbilang cukup baik walaupun masih ada siswa yang kurang percaya diri, aktif dalam belajar, disiplin dan bertanggung jawab dalam belajar. Menurut hasil wawancara dengan guru terkait indikator pertama kemandirian belajar yaitu kepercayaan diri siswa terbilang cukup baik karena siswa merasa percaya akan kemampuannya dengan mengumpulkan tugas yang sebelumnya diberikan guru walaupun hasilnya entah itu benar atau salah. Walaupun tidak semua siswa yang merasa percaya diri, karena ada siswa yang sulit mengumpulkan tugas dan harus terus di beritahu jika pengumpulannya sudah mencapai akhir. Alasannya itu karena siswa takut jika hasilnya tersebut banyak yang salah. Indikator kedua yaitu aktif belajar, guru merasa kesulitan dalam mengkondisikan siswa untuk aktif dalam pembelajaran daring karena terbatasnya handphone yang dipakai orang tua. Indikator ketiga terkait kedisiplinan belajar yaitu siswa harus sudah tahu jam belajar dan berusaha mengerjakan segala sesuatu dengan sendiri tanpa tergantung pada orang lain. Indikator terakhir yaitu terkait dengan tanggung jawab siswa yang terlihat dari kegiatan mengumpulkan tugas dengan tepat waktu.

Faktor penghambat dalam membentuk kemandirian belajar siswa di kelas III SDN Dayeuhluhur CBM cukup banyak variasinya. Mulai dari terbatasnya media handphone yang masih menggunakan milik orang tua, kondisi kuota yang cepat habis, orang tua yang sibuk bekerja dan membuat siswa banyak ketinggalan informasi serta tidak bisa mengumpulkan tugas dengan tepat waktu. Kemudian dalam pembelajaran daring ini guru kesulitan dalam menentukan kemandirian belajarnya akibat tidak adanya pantauan yang dilakukan secara langsung oleh guru.
Adapun saran dalam penelitian ini bagi guru dan orang tua siswa yang ikut berperan dalam proses pembelajaran daring yaitu sebagai berikut:

1. Guru harus lebih kreatif dan memberikan inovasi yang membuat siswa merasa termotivasi dalam melaksanakan pembelajaran daring, menciptakan suasana yang menyenangkan agar prosesnya tidak membuat siswa merasa bosan dan lebih ditingkatkan kembali komunikasi antara guru dengan siswa ataupun dengan orang tua siswa.

2. Peranan orang tua harus lebih memahami lagi terkait pembelajaran yang dilakukan anaknya ketika di rumah, karena pada dasarnya orang tua merupakan pondasi utama supaya anaknya dapat mengikuti proses pembelajaran daring dengan baik. Terutama dalam mengembangkan kemandirian belajar anaknya peran orang tua hanya membimbing dan bukan untuk membantunya setiap saat. Orang tua harus membiasakan anaknya mengerjakan apapun dengan berusaha sendiri agar kemandirian belajar siswa dapat terus terlatih dan menyempatkan waktunya untuk sering membimbing siswa ketika belajar di rumah.

\section{DAFTAR RUJUKAN}

Ariananda, E. S., Hasan, S., \& Rakhman, M. (2014). Pengaruh Kedisiplinan Siswa di Sekolah Terhadap Prestasi Belajar Siswa Teknik Pendingin. Journal of Mechanical Engineering Education, 1(2), 233-238.

Bilfaqih, Y., \& Qomarudin, M. N. (2015). Esensi Pengembangan Pembelajaran Daring. Yogyakarta: Penerbit Deepublish.

Fatihah, M. Al. (2016). Hubungan Antara Kemandirian Belajar dengan Prestasi Belajar PAI Siswa Kelas III SDN Panularan Surakarta. At-Tarbawi: Jurnal Kajian Kependidikan Islam, 1(2), 197208.

Isnawati, N., \& Samian. (2015). Kemandirian Belajar Ditinjau dari Kreativitas Belajar dan Motivasi Belajar Mahasiswa. Jurnal Pendidikan Ilmu Sosial, 25(1), 128-144. Retrieved 
http://journals.ums.ac.id/index.php/jpis/a rticle/viewFile/825/548

Nasution, M. K. (2017). Penggunaan Metode Pembelajaran Dalam Peningkatan Hasil Belajar Siswa. STUDIA DIDAKTIKA: Jurnal Ilmiah Bidang Pendidikan, 11(1), 9-16.

Purwanto, A., Pramono, R., Asbari, M., Santoso, P. B., Wijayanti, L. M., Hyun, C. C., \& Putri, R. S. (2020). Studi Eksploratif Dampak Pandemi COVID-19 Terhadap Proses Pembelajaran Online di Sekolah Dasar. EduPsyCouns: Journal of Education, Psychology and Counseling, 2(1), 1-12.

Rijal, S., \& Bachtiar, S. (2015). Hubungan antara Sikap, Kemandirian Belajar, dan Gaya Belajar dengan Hasil Belajar Kognitif Siswa. Jurnal Bioedukatika, 3(2), 15-20. https://doi.org/10.26555/bioedukatika.v3 i2. 4149

Siyoto, S., \& Sodik, M. A. (2015). Dasar Metodologi Penelitian (Cetakan 1; Ayup, ed.). Yogyakarta: Literasi Media Publishing.

Sugiyono. (2015). Metode Penelitian Pendidikan: Pendekatan Kuantitatif, Kualitatif, dan $R \& D$. Bandung: Alfabeta.

Suhandi, A., \& Kurniasari, D. (2019). Meningkatkan Kemandirian Siswa Melalui Model Pembelajaran Kontekstual di Kelas IV Sekolah Dasar. Jurnal Gentala Pendidikan Dasar, 4(1), 125137.

Suryadi, Erlamsyah, \& Yusri. (2016). Hubungan Kemampuan Menyelesaikan Tugas-
Tugas Pelajaran Dengan Hasil Belajar Siswa. Jurnal Educatio: Jurnal Pendidikan Indonesia, 2(2), 14-18.

Suyono, \& Hariyanto. (2016). Belajar dan Pembelajaran. Bandung: PT Remaja Rosdakarya.

Syam, A., \& Amri. (2017). Pengaruh Kepercayaan Diri (Self Confidence) Berbasis Kaderisasi IMM Terhadap Prestasi Belajar Mahasiswa (Studi Kasus di Program Studi Pendidikan Biologi Fakultas Keguruan dan Ilmu Pendidikan Universitas Muhammadiyah Parepare). Jurnal Biotek, 5(1), 87-102.

Yanti, M. T., Kuntarto, E., \& Kurniawan, A. R. (2020). Pemanfaatan Portal Rumah Belajar Kemendikbud sebagai Model Pembelajaran Daring di Sekolah Dasar. ADI WIDYA: Jurnal Pendidikan Dasar, 5(1), 61-68. https://doi.org/10.1017/CBO9781107415 324.004

Yasmin, F. L., Santoso, A., \& Utaya, S. (2016). Hubungan Disiplin dengan Tanggung Jawab Belajar Siswa. Jurnal Pendidikan: Teori, Penelitian Dan Pengembangan, 1(4), 692-697.

Yustika, G., \& Prihatnani, E. (2019). Peningkatan Hasil dan Keaktifan Belajar Siswa Melalui NHT. Jurnal Cendekia: Jurnal Pendidikan Matematika, 3(2), 481-493.

Zakirman, \& Rahayu, C. (2018). Popularitas WhatsApp Sebagai Media Komunikasi dan Berbagi Informasi Akademik Mahasiswa. Jurnal Perpustakaan, Arsip Dan Dokumentasi, 10(1), 27-38. 